\title{
RISK MANAGEMENT MODEL FOR TRANSPORTATION COMPANY
}

\author{
Viktorija Stasytyté ${ }^{1}$, Raminta Pilioniené⿱ ${ }^{2}$ \\ Department of Finance Engineering, Faculty of Business Management, Vilnius Gediminas Technical University, \\ Saulètekio al. 11, Vilnius, Lithuania \\ E-mails: ${ }^{1}$ viktorija.stasytyte@vgtu.lt (corresponding author); ${ }^{2}$ raminta.pilioniene@stud.vgtu.lt
}

\begin{abstract}
There are different risk management models developed in scientific as well as in practical literature, but they are usually of general manner and should be adapted for particular company or field of activity. The paper aims at developing a risk management model for transportation company, based on the prevalent theoretical provisions of risk management activity. The separate attention is given to risk identification stage as it proves to be a critical step of risk management process. Different methods, such as SWOT, PEST, financial analysis and questionnaire are applied to identify risks in transportation sector company. The proposed model includes the basic steps of risk management process and ends with a detailed risk management plan preparation.
\end{abstract}

Keywords: risk identification, risk map, risk management model, transportation sector.

JEL Classification: R4; L21; D81; G32.

\section{Introduction}

The ever growing globalization of financial markets, the growth of the market itself, as well as separate country economic internationalization and the financial world has become more hazardous than ever (Akhmetov, Rysaeva 2015; Lee, Lin 2016). In this context, organizations are now more frightened by financial crisis and sistemic risk menace which drives them to take interest in risk management and control (Beasley et al. 2005; Chapman 2007; Liebenberg, Hoyt 2003). The importance of risk in financial activities is bigger not only in countries intensively setting up market mechanisms, but in devoloping countries too. Effective risk analysis creates the space to prepare for prospective negative events and minimize possible damage by choosing the right risk reduction tools.

Nevertheless, risk evaluation, prognozing and managing is so far an economic aspect which doesn't receive enough attention as from businessmen, as from state institutions that have to do with business development (Gorzeń-Mitka, 2012). Negative non-managed risk effect consequences are felt even stronger not only in financial field, but also in many other public life areas. It is nearly impossible to avoid risk completely, therefore it is highly important to manage this sphere correctly and most importantly invest in it.

Risk management is a constantly developing business process. It takes important place in companies performing various activities (Crockford
1982; Dionne 2013). Enterprise risk management is a systematic and integrated approach to the management of the total risks that is faced by the company (Dickinson 2001). Alhough there is sufficient amount of risk management models developed in scientific as well as in practical literature, they are usually of general manner and should be adapted for particular company or field of activity (Hafezi, Akhavan 2014; Oliva 2016; Kim et al. 2016). Proper attention is given to models of risk management in projects (Tamošiūnienè 1999).

The research problem - the lack of enterprise risk management models for certain business sectors.

The research objective - to prepare risk management model for transportation sector enterprise by analysing and identifying the company's risks.

In order to achieve the objective of the article, the following tasks were fulfilled:

- to analyze enterprise risk identification methodology;

- to perform risk identification in a transport company;

- to evaluate the risks and propose ways to reduce them;

- to propose risk management model for transport company.

Research methods: scientific literature analysis, comparative analysis, SWOT analysis, PEST analysis, questionnaire, graphical visualization. 


\section{Methodology}

In order to determine JSC „Cargo Transportation“ risks and offer enterprise risk management plan, it is appropriate to first briefly introduce the current situation of the company and its environment in a competetive context. In the following stages of the investigation the risks incurred by the analyzed company will be distinguished. This will be done using PEST and SWOT methods.

PEST analysis is a useful strategic planning tool that can allow to understand the factors of the market growth and fall, the business position, potential and direct operations. The acronym PEST stands for Political, Economic, Social and Technological features (Boddy 2011).

PEST analysis has such advantages as a simple and easy-to-use framework for analysis, helps to reduce the impact and effects of potential threats to the organization, enables to assess implications of entering new markets both nationally and globally. The drawbacks of this method state that it can oversimplify the information that is used for decision-making, the process has to be conducted regularly, the quality of external information is often restricted.

As PEST analysis generally pays attention only to external factors, the risks distinguished using this method will usually be related with external company environment. To do more thorough analysis, including company internal issues, SWOT analysis is needed.

SWOT analysis looks at not only the company's internal operations, but also evaluates the competitors in the market and the ongoing activities (Kučinskienè et al. 2012). Due to the constant innovation of strategic management in recent decades, the SWOT model is exceptionally popular among researchers and practitioners (Shang, Pheng 2014; Comino, Ferretti 2016). This tool helps to perform detailed environment analysis (threats and opportunities for the business environment), as well as the analysis of organization (a search for strengths and weaknesses of the business sector). SWOT analysis is a widely used tool for analyzing the internal and external environments to support a systematic approach and strategic decisions.

Although the SWOT tool has been started in the 50's and 60's, Weihrick (1982), who introduced the SWOT matrix as a situation analysis tool, can be considered as one of the most important persons in this area, as he submitted some classic analysis samples.

Later SWOT has been used and described in many works of strategic planning theme. Dyson
(2004) suggests that although this tool seems out of date, compared with the last years' models, such as enterprise resource planning or competence based models, is still an extremely flexible system that can be easily integrated with the newly proposed models. While strategic planning can be done using a variety of measures, in recent years SWOT has been used in thousands of researches and hundreds of documents (Ghazinoory et al. 2011).

The key advantages of SWOT analysis are its simplicity and time-effectiveness. The method allows to determine possible strategic areas of company development. Such analysis thoroughly integrates the impact of internal and external factors (Mikulskiene 2011). Scientific works also list a number of weaknesses and limitations in the SWOT model and methodology (uncertainty of the sources of information, subjectivity of expert opinion), as well as some variations for this tool and possibilities to combine it with other instruments and techniques.

For further investigation a questionnaire method was used. The survey, which will be attended by JSC „Cargo Transportation“ employees, and also by other transport company employees, will reveal additional risks and will allow to find the ways how these risks can be managed and reduced.

A questionnaire survey was chosen because of its performance which requires a minimum of time and money, but the information is available from a larger number of respondents. According to the respondents' responses it is possible to make a preliminary conclusion on the significance of the problem. The survey questionnaire consisted of 21 questions.

The research organization: the study was carried out in May 2015. The test sample was formed in a convenient way: the employees of several transport companies were interviewed. JSC „Cargo Transportation" employs 34 workers. According to the Lithuanian Department of Statistics in 2014 transport companies have employed 72108 workers. The survey questionnaires were distributed to 100 research subjects, which consisted of JSC „Cargo Transportation“ company employees and employees from other companies, too. Only 84 questionnaires were returned. 5 questionnaires were not fully completed, therefore they did not take part in the final results of the investigation. The questionnaire survey was based on the research ethics principles listed in scientific literature (Žydžiūnaite et al. 2008). 


\section{Risk identification using different methods}

The PEST analysis of the transportation company is performed in this chapter.

Economic environment. Currently, the industry is still recovering from the 2009 crisis. Demand is growing, sales are growing. The company in Lithuania has a lot of competitors that are as well engaged in transport activity. Compared with the major Western countries, Lithuania's economy is relatively small, so it quickly responds to the crisis, but also quickly reacts to any improvement in the situation, to say Lithuania's economy is much more resilient and tends to adapt to different circumstances, compared with the world's major economies.

Political-legal environment. Companies must pay in advance the taxes to the state, a significant amount of revenues are freezed bu value added tax. After the car drives through the company's gate, all the charges are counted immediately, and if they are not paid according to terms, the fines are specified.

Social-cultural factors. After examination of the social and cultural impact on the environment it was observed that this type of environment often leads to the structure of consumer needs and behavior while using the company services. Freight transport demand is especially strongly influenced by the willingness of people to change their place of residence. The company participates in various social and charity campaigns.

Scientific-technological factors. New information and other technologies facilitate not only the access to corporate services in virtual environments, but also simplify and accelerate the opportunity to provide services. In addition, the new mass media and technology used for advertising production allows to create more interesting and effective advertising, which helps to popularize the company around the world.

Improving the given services is the question relevant to each profit-seeking organization. Freight transportation market service improvement has become particularly relevant due to strong increase in competition between freight services offering companies. Increased competition and a drop in freight rates offers the possibility to survive in the market only for effectively operating freight organizations.

Summing up the results of the PEST analysis, it can be concluded that the company faces two important external environment risks - taxes to the state and strong competitors. On the one hand, the company sometimes can be late in paying taxes. If tax is not paid on time, calculation of fine begins, which is not beneficial for businesses because it makes the debt grow. In addition, the state can raise taxes for business, which would increase the company's costs. And a large number of competitors is due to activity of the company - Lithuania holds quite a lot of freight companies, whereas the country has a favorable geographical location.

Furher the SWOT analysis of JSC "Cargo Transportation" was carried out (Table 1).

Table 1. SWOT analysis of JSC „Cargo

Transportation" (Source: compiled by the authors)

\begin{tabular}{|c|c|}
\hline $\begin{array}{r}\text { STRE } \\
\text { - an } \\
\text { ma } \\
\text { nat } \\
\text { - fun } \\
\text { sys } \\
\text { unc } \\
\text { rol } \\
\text { - ong } \\
\text { cou } \\
\text { - rap } \\
\text { ket } \\
\text { - lon } \\
\text { - skil } \\
\text { key } \\
\text { - goo } \\
\text { and }\end{array}$ & $\begin{array}{l}\text { WEAKNESSES: } \\
\text { - weaker than competi- } \\
\text { tors' marketing skills; } \\
\text { - clients do not get noti- } \\
\text { fications about cargo } \\
\text { location / condition; } \\
\text { - relatively old vehicles; } \\
\text { - an investigation is not } \\
\text { conducted to deter- } \\
\text { mine unmet needs of } \\
\text { consumers; } \\
\text { - operating software and } \\
\text { hardware problems. }\end{array}$ \\
\hline $\begin{array}{l}\text { OPPORTUNITIES: } \\
\text { - new client search; } \\
\text { - favorable conditions to } \\
\text { improve the company's } \\
\text { activities; } \\
\text { - market share increase } \\
\text { while entering the } \\
\text { global market; } \\
\text { - new customers needs } \\
\text { clarification; } \\
\text { - new technology. }\end{array}$ & $\begin{array}{l}\text { THREATS: } \\
\text { - development of com- } \\
\text { petitors' services; } \\
\text { - potential employee } \\
\text { transition to competi- } \\
\text { tors; } \\
\text { - customer bankruptcy: it } \\
\text { is impossible to recov- } \\
\text { er money for services } \\
\text { rendered; } \\
\text { - political - legal envi- } \\
\text { ronment instability. }\end{array}$ \\
\hline
\end{tabular}

The SWOT analysis can determine the following JSC "Cargo Transportation" risks, although some have been already identified during PEST analysis:

1. Relatively old vehicles;

2. Unsatisfied customers;

3. Customer insolvency / bankruptcy;

4. Competitors' growth (already established during PEST analysis);

5. The political-legal environment instability, taxes (already established during PEST analysis).

Questionnaire survey has been performed in order to supplement the list of distinguished risks, 
which was formed after the PEST and SWOT analysis. The survey involved 100 respondents the employees of transport companies.

The results are analyzed by first reviewing of respondents' demographic data, but it will not be presented in this article.

Although all transport companies are engaged in the same or similar activities, but different types of enterprises can distinguish different types of risks. Therefore, freight companies' employees were asked about their company activity. Since, as shown by a survey conducted, the majority of survey participants $(60$ percent $)$ is working with international transportation companies, the survey results will be concentrated on the risks they face. 15 percent of respondents are working with local transportation companies, 15 percent - in the companies that are engaged in the carriage of passengers and 9 percent of companies transfer hazardous goods.

The results show that study participants evaluate the activity management of the company well (40 percent) or satisfactory (40 percent). 11 percent of the surveyed said that their company is managed very well. The distribution of the responses reveals that the company organization and management is performed well, but there is a need to improve certain aspects. Activity of enterprise is assesed poorly by 6 percent of freight company employees 3 percent say it is very bad. So, as one of the risks lack of efficient organization of the company's activities can be identified.

In literature (Ališauskas 2005; Melnikas et al. 2000; Strazdas et al. 2003; Shwandar, Gorfinkel' 2004) risk classification spectrum is quite broad. For the study the company's internal factors (manufactured products, employees, available technolo- gy, business strategy, etc.) were selected, as well as near external environment (competitors, suppliers, customers, etc.), because the latter influences the business directly. Taking into account the specifics of innovative activities and recommendations of the scientists in this field to identify risks (Medynskiy, Sharshukova 1997), it is possible to concentrate on the company's innovative operational risk factors. For transport companies, according to a survey conducted, it is the economic risk (30 percent), which is inseparable part of Lithuanian economic growth, and technological risk (30 percent), which are related to vehicle renewal. Geopolitical risks (15 percent), social risks (15 percent) and environmental risks (10 percent) are also important to respondents.

The most commonly used risk management techniques in transportation companies are risk avoidance ( 25 percent), banking services (guarantees) (25 percent) and insurance ( 25 percent). Very few shipping companies seek to avoid risk by consulting support ( 5 percent), dividing the risks between the participants ( 5 percent), through specialist support (5 percent) or by accumulating reserves ( 5 percent). Only 5 percent of respondents say their company has reserve funds for emergencies or refuses to conduct risky activities.

It was also intended to find out whether the survey participants consider business risk management is needed. The research in the company JSC "Cargo Transportation" reveals that business risk management is usually needed ( 70 percent.).

Figure 1 provides respondents' opinion on the most important reasons why the timely identificated risk is not managed ( 5 - very important reason, 1 - the least important reason).

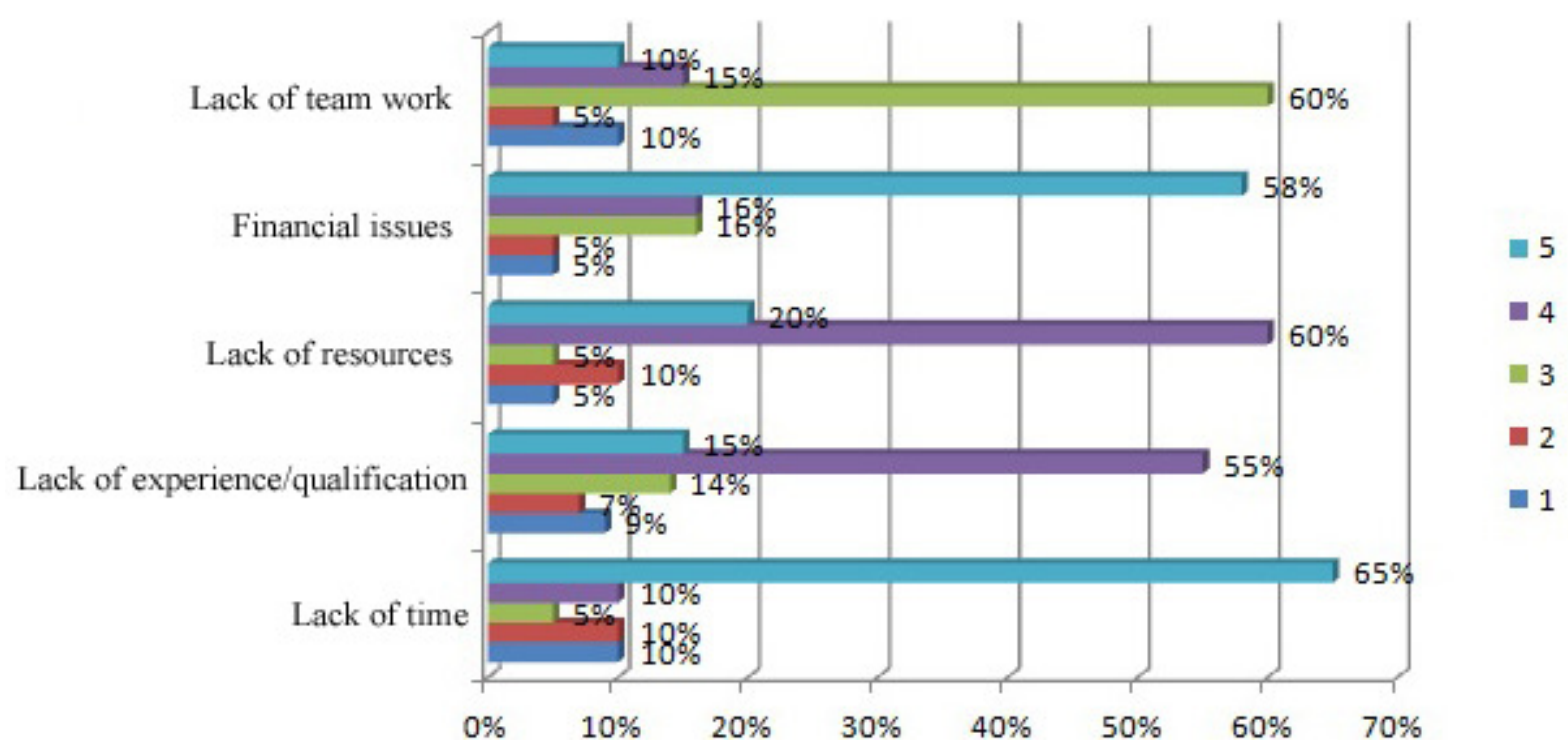

Fig. 1. The most important reasons why timely identificed risk is uncontrolled (Source: compiled by the authors) 


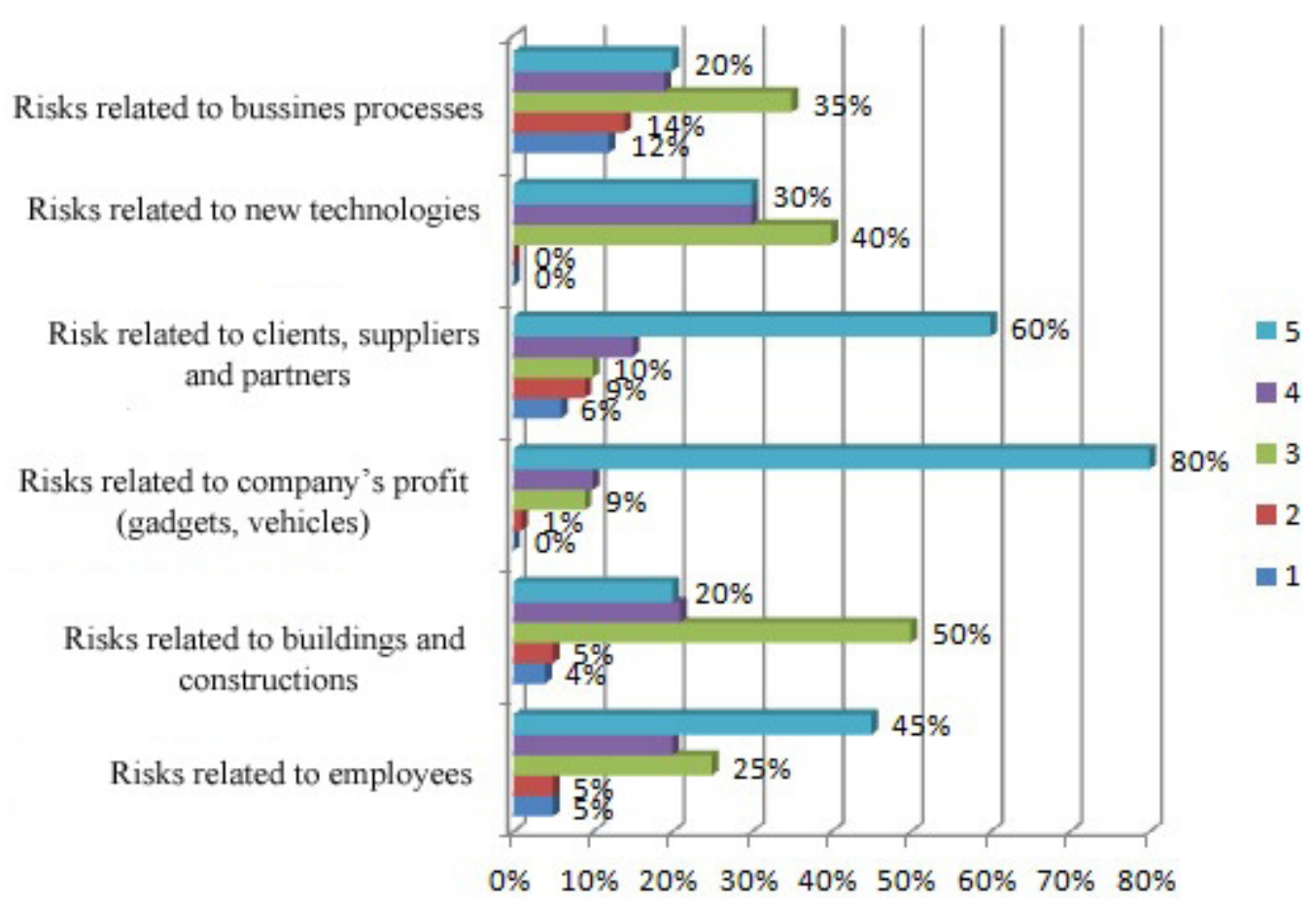

Fig. 2. The groups of key pure risks (only causing loss) in transport company (Source: compiled by the authors)

According to the survey respondents participated, the risk identificated in time is uncontrolled because of lack of time (65 percent) and financial problems (58 percent). Often risk mismanagement happens due to a lack of resources (60 percent) or lack of experience / lack of qualification (55 percent). As it is revealed by the results of the study, risks are rarely uncontrolled because of a lack of teamwork.

The analysis of the financial risks inherent in the transport company found that the most relevant to the transport enterprise is credit risk (30 percent). The companies also face liquidity ( 25 percent), interest rate changes (25 percent) and currency exchange rate risks ( 25 percent).

Figure 2 presents the main pure risk factors (causing only loss) for the transport group of companies $(5$ - very important factor, 1 - the least important factor).

As it is shown by a survey conducted, the majority of losses of transport companies are influenced by the risk associated with the company's assets ( 80 percent), or the risks associated with customers, suppliers and partners (60 percent). Slightly less losses are influenced by the risk associated with employees (45 percent), with real estate (50 percent), with information technology ( 40 percent) and with business processes (35 percent). So, the following major pure risks are distinguished: risks associated with the company's assets and risks associated with customers, suppliers and partners.

Major speculative risk factors (which may cause a loss or bring profit) for a transport company is service pricing (60 percent of respondents indicated this as a very important factor). Also a very important factor is the introduction of new services on the market (70 percent) and a merger with another company (55 percent). Slightly less important speculative risk factors for transport company is investing (50 percent), the entrance into a new market (50 percent) and business development (35 percent).

After performing the transport company employee survey, additional risks were distinguished. In particular, it is a financial risk, combining credit, liquidity, interest rate and exchange rate risk, since all four risks were identified by the employees in approximately equal frequency. Other important risk group that received a lot of scores from respondents, was a group of risks associated with customers, suppliers and partners. Taking into account the specificity of company activity, a specific example of risk from this field is a noncompliance of customer liabilities.

Also, a survey done revealed that employees do not have knowledge on risk management and do not know what the risk management process is, so the risk management model proposed in the article should be particularly beneficial in practice. 


\section{Risk analysis, assessment and formation of risk management model}

According various risk management methodologies, after risk identification step the risk assessment (or risk analysis) takes place (ISO 2009; COSO 2004). Quantitative risk assessment techniques usually receive more attention as they help to analyse the required information that can be used for further work with risks identified and analysed. Qualitative techniques, on the other hand, help in determining causes or consequences of certain events and provide a linguistic description of risky situations. However, an efficient entity's risk assessment methodology comprises a combination of qualitative and quantitative techniques (Stasytyte 2012). The examples of possible risk assessment techniques are risk register and risk map, and both of them can be qualitative, as well as quantitative.
Thus, in order to analyse the risks identified earlier in the paper, a risk register is being formed. Some of the risks in the register are presented in more details than during risk identification step, others, on the contrary, are combined.

As it can be seen from Table 2, JSC „Cargo Transportation" is subject to risks of various strength. One of the major risk sis related with vehicles. Due to the depreciation of cars and equipment, as well as because of breakdowns the company should constantly buy new assets, and this, in turn, reduces profit.

Noncompliance of customer, supplier and partner liabilities also makes up a threat for company activity efficiency. Often company clients remain indebted for the services provided. This fact hardens company cash flow balance.

Table 2. Risk register (Source: compiled by the authors)

\begin{tabular}{|c|c|c|c|c|c|}
\hline \multirow[b]{2}{*}{ No } & \multirow[b]{2}{*}{ Risk description } & \multicolumn{3}{|c|}{ Current level of risk } & \multirow[b]{2}{*}{ Response to risk } \\
\hline & & Likelihood & Impact & $\begin{array}{l}\text { Overall } \\
\text { rating }\end{array}$ & \\
\hline 1. & $\begin{array}{l}\text { Risk related with company } \\
\text { assets (equipment, } \\
\text { vehicles) }\end{array}$ & Likely & Major & Extreme & $\begin{array}{l}\text { It is required to purchase newer vehicles } \\
\text { or equipment. It is worth to consider pos- } \\
\text { sibility to have own garage in order to } \\
\text { reduce repair costs. Insurance can be used. }\end{array}$ \\
\hline 2. & $\begin{array}{l}\text { Risk related with custom- } \\
\text { ers, suppliers and partners }\end{array}$ & Likely & Major & Extreme & $\begin{array}{l}\text { Agreements with customers, suppliers and } \\
\text { partners should be made where all agree- } \\
\text { ment provisions should be mentioned. } \\
\text { Agreement should pass the legal review. }\end{array}$ \\
\hline 3. & $\begin{array}{l}\text { Risk related with infor- } \\
\text { mation technologies }\end{array}$ & Rare & Moderate & Low & $\begin{array}{l}\text { It is required to purchase a program allow- } \\
\text { ing for customers to track their cargo and } \\
\text { its condition. }\end{array}$ \\
\hline 4. & $\begin{array}{l}\text { Risk related with business } \\
\text { processes (improper busi- } \\
\text { ness process management) }\end{array}$ & Possible & Moderate & Medium & $\begin{array}{l}\text { Employees with adequate transport engi- } \\
\text { neering knowledge are required. }\end{array}$ \\
\hline 5. & Stronger competition & Likely & Major & Extreme & $\begin{array}{l}\text { A suitable price of services should be set. } \\
\text { The price should not be higher than com- } \\
\text { petitors' price. A proper quality of ser- } \\
\text { vices also should be retained. }\end{array}$ \\
\hline 6. & $\begin{array}{l}\text { Financial risk. It covers } \\
\text { credit, liquidity, interest } \\
\text { rate and currency ex- } \\
\text { change rate risk. }\end{array}$ & Possible & Major & High & $\begin{array}{l}\text { Horizontal and vertical analysis of finan- } \\
\text { cial statements, as well as financial ratios } \\
\text { analysis of the company should be per- } \\
\text { formed. A suitable debt ratio should be } \\
\text { sustained. Gathering additional reserves } \\
\text { can help. }\end{array}$ \\
\hline 7. & $\begin{array}{l}\text { Noncompliance of cus- } \\
\text { tomer liabilities }\end{array}$ & $\begin{array}{l}\text { Almost } \\
\text { certain }\end{array}$ & Major & Extreme & $\begin{array}{l}\text { Advanced payments should be gathered; } \\
\text { settlement for provided services should be } \\
\text { strongly required. Factoring service can be } \\
\text { used. }\end{array}$ \\
\hline 8. & $\begin{array}{l}\text { Instability of political and } \\
\text { legal environment, taxes }\end{array}$ & Possible & Moderate & Medium & $\begin{array}{l}\text { This is an external risk, so it is hardly } \\
\text { manageable. } \\
\text { Gathering additional reserves can help. }\end{array}$ \\
\hline
\end{tabular}


Lower risks are related with information technologies and business processes, ex. clients are not provided with information about the place and condition of the cargo. These risks are not critical to company existence, however, their reduction would help to improve the quality of the services provided, would attract new customers. On the other hand, it requires investments, as well.

Further all the specified risks are presented on the risk map (Fig. 3).

The risk map presents the identified risks according their impact and likelihood. It can be seen from Figure 3 that the majority of identified risks are concentrated in the high likelihood/high impact quadrant.

Next, based on the obtained results from SWOT and PEST analysis, questionnaire and considering the proposed risk reduction instruments in the risk register, the intuitive risk management model for transportation company could be proposed (Fig. 4).

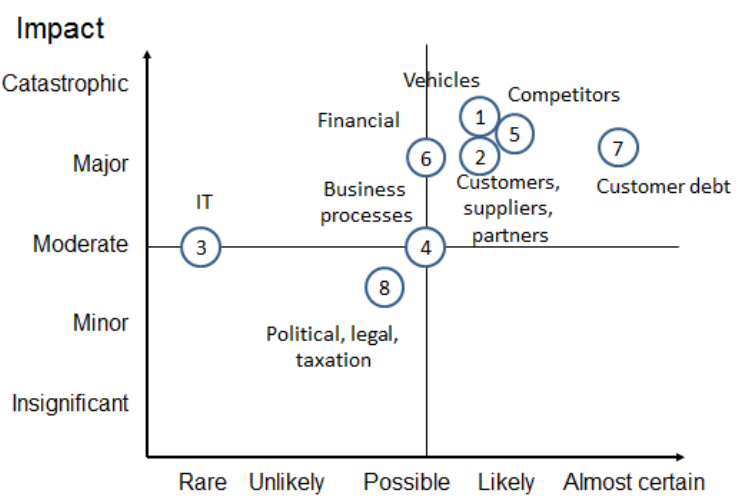

Likelihood

Fig. 3. Risk map for transportation company (Source: compiled by the authors)

The risk management model starts from risk identification. Some of the parts of risk identification were described and applied the the performed research, others were not (eg. financial analysis, analysis of competitors), but still it is seen as a suitable means to analyse the company activity and to identify additional risks.

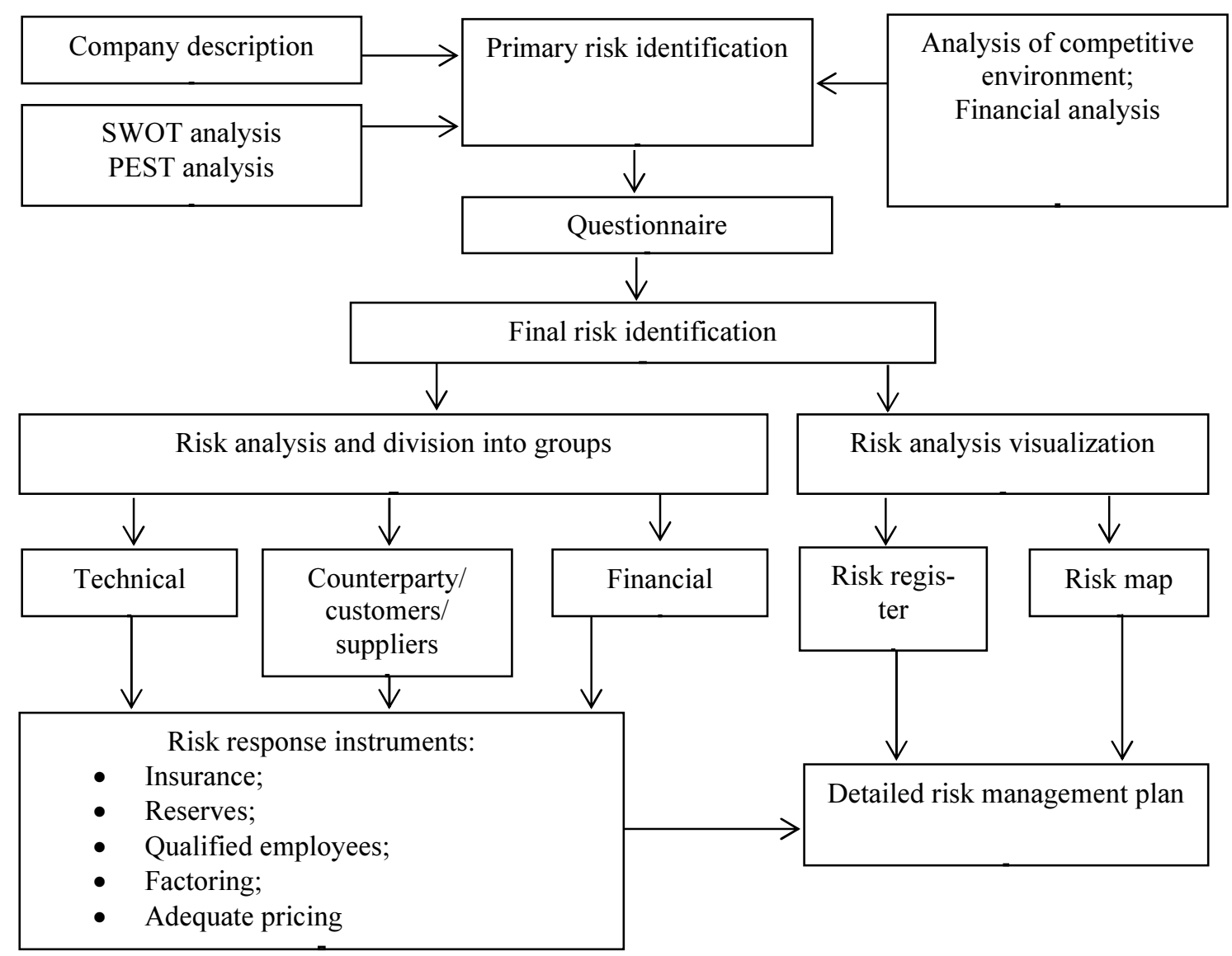

Fig. 4. The risk management model for transportation company (Source: compiled by the authors) 
The proposed risk management model mainly represents the necessary process elements of risk management. There are some parts of the model that are suitable for any company, such as risk identification methods or risk analysis visualization. However, there are some points typical mainly for transportation company, such as particular groups to which risks are divided, as well as proposed risk response instruments. Also, each company, even operating in the analysed transportation sector, should carefully apply the model and make minor adjustments to it. The final step of the model is a classical element of risk management - the preparation of risk management plan. Because of limited amount of the paper, the risk management plan for transportation company will not be analysed in details, but it can be a good area for further research and practical discussions.

\section{Conclusions}

Nowadays business companies are increasingly concerned about possible financial crisis and the threat of systemic risks, what, in turn, encourages them to take an interest in risk management and control. Adequate attention paid to risk in a company can substantially reduce resources spent to coping with consequences after the risky event happens.

One of the most important step in risk management process is risk identification. It can be done by many methods, and particular methods of a combination of methods should be selected considering the field of company activity, company size and policy of the company shareholders.

Conducting risk analysis, it is useful to divide risks into groups. In transportation sector these groups could be technical risk, counterparty/ customers/suppliers risk and financial risk. Also, for better risk perception some risk visualization techniques should be used, such as risk register and risk map.

The proposed risk management model is primarily developed for transportation companies, but can be also used by other companies. The model includes the basic steps of risk management process and ends with a detailed risk management plan preparation.

Paying more attention to risk management in companies, assigning resources to risk management and using at least simple risk management models would help to include risk management into the corporate strategy and decision making, and, as a result, would contribute to efficient company activity.

\section{References}

Akhmetov, R.; Rysaeva, G. 2015. The problems of financial cycle modeling in the globalization of financial markets, Procedia Economics and Finance 27: 522-528.

http://dx.doi.org/10.1016/S2212-5671(15)01014-X

Ališauskas, K.; Karpavičius, H.; Šeputienè, J. 2005. Inovacijos ir projektai. VŠ Š Šiaulių universiteto leidykla.

Beasley, M. S.; Clune, R.; Hermanson, D. R. 2005. Enterprise risk management: An empirical analysis of factors associated with the extent of implementation, Journal of Accounting and Public Policy 24(6): 521-531.

http://dx.doi.org/10.1016/j.jaccpubpol.2005.10.001

Boddy, D. 2011. Management: an introduction. $5^{\text {th }}$ ed. Harlow: Pearson. 676 p.

Chapman, R. J. 2007. Simple tools and techniques for enterprise risk management. New York-Chichester-Brisbane-Toronto-Singapore: John Wiley \& Sons, Inc..

Comino, E.; Ferretti, V. 2016. Indicators-based spatial SWOT analysis: Supporting the strategicplanning and management of complex territorial systems, Ecological Indicators 60: 1104-1117.

http://dx.doi.org/10.1016/j.ecolind.2015.09.003

COSO. 2004. Enterprise Risk Management - Integrated Framework. 134 p.

Dickinson, G. 2001. Enterprise risk management: its origins and conceptual foundation, The Geneva Papers on Risk and Insurance 26(3): 360-366.

Dionne, G. 2013. Risk management: history, definition and critique. CIRRELT-2013-17.

Dyson, R. G. 2004. Strategic development and SWOT analysis at the University of Warwick, European Journal of Operational Research 152(3): 631-640. http://dx.doi.org/10.1016/S0377-2217(03)00062-6

Ghazinoory, S.; Abdi, M.; Azadegan-Mehr, M. 2011. Swot methodology: a state-of-the-art review for the past, a framework for the future, Journal of Business Economics and Management 12(1): 24-48. http://dx.doi.org/10.3846/16111699.2011.555358

Gorzeń-Mitka, I. 2012. Risk management in Polish companies, in Proceedings of the $7^{\text {th }}$ International Scientific Conference "Business and Management 2012”, 10-11 May 2012, Vilnius, Lithuania, 1090-1095.

Crockford, G. N. 1982. The bibliography and history of risk management: some preliminary observations, The Geneva Papers on Risk and Insurance 7(23): 169-179.

Hafezi, R.; Akhavan, A. N. 2014. A novel conceptual risk management model based on the future's uncertainties, in $8^{\text {th }}$ International Scientific Conference "Business and Management 2014", May 1516, 2014, Vilnius, Lithuania, p. 223-228. http://dx.doi.org/10.3846/bm.2014.028 
Innovatsionnyy menedzhment: Uchebnoe izdanie. 2004. Pod red. prof. V. A. Shvandara, prof. V. Ya. Gorfinkelya. Moskva.

International Standard ISO 31000:2009. Risk Management - Principles and guidelines. 36p.

Kim, K.; Kim, H.; Kim, S.-K.; Jung, J.-Y. 2016. i-RM: An intelligent risk management framework for context-aware ubiquitous cold chain logistics, Expert Systems With Applications 46: 463-473. http://dx.doi.org/10.1016/j.eswa.2015.11.005

Kučinskienè, M.; Žiogelytė, L.; Jatuliavičienė, G. 2012. Verslo strategija: atvejo analizé: mokomoji knyga. Vilnius: Vilniaus universiteto leidykla. 305 p.

Lee, Ch.-Ch.; Lin, Ch.-W. 2016. Globalization, political institutions, financial liberalization, and performance of the insurance industry, North American Journal of Economics and Finance 36: 244-266. http://dx.doi.org/10.1016/j.najef.2016.01.007

Liebenberg, A. P.; Hoyt, R. E. 2003. Determinants of enterprise risk management: evidence from the appointment of chief risk officers, Risk Ma-nagement and Insurance Review 6: 37-52. http://dx.doi.org/10.1111/1098-1616.00019

Medynskiy, V. G.; Sharshukova, L. G. 1997. Innovatsionnoe predprinimatel'stvo: Uchebnoe posobie. Moskva: INFRA-M.

Melnikas, B.; Jakubavičius, A.; Strazdas, R. 2000. Inovaciju vadyba. Vilnius: Technika.

Mikulskienè, B. 2011. Sprendimu priemimo metodai viešajam valdymui. Vilnius: Leidykla MES.
Oliva, F. L. 2016. A maturity model for enterprise risk management, International Journal of Production Economics 173: 66-79. http://dx.doi.org/10.1016/j.ijpe.2015.12.007

Shang, G.; Pheng, L. S. 2014. The Last Planner System in China's construction industry - A SWOT analysis on implementation, International Journal of Project Management 32: 1260-1272. http://dx.doi.org/10.1016/j.ijproman.2014.01.002

Stasytyte, V. 2012. Risk identification and visualization techniques for reasonable enterprise risk management, in $2^{\text {nd }}$ International Scientific Conference "Whither our economies-2012", 15-16 October 2012, Vilnius, Lithuania. Vilnius: Mykolo Romerio universitetas. ISSN 2029-8501.

Strazdas, R.; Jakubavičius, A.; Gečas, K. 2003. Inovacijos: finansavimas, rizikos kapitalas. Vilnius: Lietuvos inovacijų centras.

Tamošiūnienè, R. 1999. Risk analysis in the investments of construction projects, Statyba 5(1): 59-67. http://dx.doi.org/10.1080/13921525.1999.10531434

Weihrich, H. 1982. The TOWS matrix a tool for situational analysis, Long Range Planning 15(2): 54-66. http://dx.doi.org/10.1016/0024-6301(82)90120-0

Žydžiūnaitè, V.; Rupšienè, L.; Bitinas, B. 2008. Kokybiniu tyrimu metodologija. Klaipėda: S. Jokužio leidykla-spaustuvè. $304 \mathrm{p}$. 